\title{
The Catholic Church through the Eyes of Contemporary Czechs and Contemporary Czechs through the Eyes of the Catholic Church Between Distrust and Expectation David Václavík
}

A number of sociological studies have noted that the secular profile of the Czech Republic is extraordinary even within post-communist Central and Eastern Europe, where for almost half a century religious development was decisively formed by an explicitly anti-religious regime. ${ }^{1}$ Special attention is raised by the difference in religious profile when comparing the populations of the Czech Republic and the Slovak Republic, i.e., two countries that for a significant part of the $20^{\text {th }}$ century constituted one state. ${ }^{2}$

However, in recent years several studies by Czech authors have been published ${ }^{3}$ challenging the wide-spread thesis, according to which Czech society is the most atheistic society (at least) in contemporary Europe. They argue that this thesis is based on a misunderstanding of the character of Czech religiosity, whose key features rather are a marked tendency to privatization and individualization and a high level of distrust of traditional religious institutions, especially large Christian churches. In that they draw on data from empirical surveys which in their view prove the ungrounded substitution of Czech "atheism" for individualized and privatized spirituality. In this context they claim that only a relatively limited segment of the Czech population can be viewed as convinced (i.e., real) atheists. A significant number of persons who repeatedly rank themselves as so-called non-religious in fact constitute a heterogeneous group, not infrequently bearing the features of various forms of alternative religiosity or privatized spirituality.

\section{Modern history of Czech god(less)ness}

One of the key factors involved in the development of the problematic and ambiguous attitude of the majority Czech population to religion are the dramatic social and demographic transformations the Czech society underwent in the course of the $20^{\text {th }}$ century.

1 Cf. e.g. Siniša ZRINŠČAK, Generations and Atheism: Patterns of Response to Communist Rule Among Different Generations and Countries, Social Compass 2/2004, pp. 221-234; Olaf MÜLLER, Secularization, Individualization, or (Re)vitalization? The State and Development of Churchliness and Religiosity in Post-Communist Central and Eastern Europe, Religion and Society in Central and Eastern Europe 1/2011, pp. 21-37.

2 Cf. e.g. Andrew M. GREELY, Religion in Europe at the End of the Second Millennium: A Sociological Profile, New Brunswick: Transaction Publishers, 2003; Paul FROESE, Secular Czechs and Devout Slovaks: Explaining Religious Differences, Review of Religious Research 3/2005, pp. 269-283.

3 Cf. e.g. Dana HAMPLOVÁ, Institucionalizované a neinstitucionalizované náboženství v českém poválečném vývoji, Soudobé dějiny 2-3/2001, pp. 294-311; Dana HAMPLOVÁ \& Zdeněk R. NEŠPOR, Invisible Religion in a 'Non-Believing' Country: The Case of the Czech Republic, Social Compass 4/2009, pp. 581-597; David VÁCLAVÍK, Náboženství a moderní česká společnost, Praha: Grada, 2010. 
Already the period of the so-called Czechoslovak Republic $(1918-1938)^{4}$ indicated in what direction the attitudes towards religion and religious institutions would develop. As its main features it is possible to identify distrust in religious institutions, tendency to privatization of religion and growing religious indifferentism. The development in that period also showed that the decisive role in the transformation of the Czechs' relationship to religion was played by disidentification with the dominant Catholic Church. The course of this relationship was most dramatic in the first years of the existence of the autonomous state, i.e., approximately till $1925 .{ }^{5}$

After WWII the described trends were reinforced by two factors: the removal of the German minority (ca. 2.6 million people) from the Czech borderlands in 1945-1947 and the installation of the communist regime in 1948. As a result of the removal of the German population the renewed Republic lost a significant part of the population professing mostly the Catholic faith. But the removal had a marked bearing on other denominations as well (the German Church of the Augsburg Confession, the New Apostolic Church and the Old Catholic Church).

More momentous, however, were the demographic and socio-economic changes brought about by the removal. The continuous area of the Czech borderlands (the so-called Sudetenland) was essentially depopulated and soon resettled. It was especially important that resettling the borderlands took place by the the transfer of individuals directed from above (not entire communities as, e.g., in the settling of Silesia in Poland), who were often recruited from lower social strata, were less educated and politically inclined to the left. Not infrequently they were "politically proven" persons, sympathizing with the communist party, as a result of which there was a higher number of persons 'without confession' among them.

The stated manner of resettling the originally ethnically German borderlands resulted in the disruption of historical family and community ties and disintegration of local religious memory. In the Czech borderlands there arose a situation where the typical image was a nuclear family 'rooted' in a place only in the first generation without any ties to the place and local community. As a result of that there almost instantaneously disappeared local religious and cultural traditions such as pilgrimages or collective celebrations of feasts. Due to the disruption of social ties to the place, material manifestations of religious life (churches, chapels, devotional pillars) were gradually devastated. Also, intensive interference in the religious infrastructure took place, which in some regions resulted in essential paralysis of the activity of religious groups. The majority of German priests had to leave their parishes, and the same reasons led to the cessation of a number of convents.

After 1948, when the communist regime was installed in Czechoslovakia, the social, demographic and cultural transformations of the Czech society continued, manifested in a marked decrease of participation in religious activities. This dynamic was accelerated not in the 1950s, when the

41918 is an important milestone in the development of Czech society. After several centuries of being an Austrian (Habsburg) dominion, Czech statehood was renewed when a new democratic state of Czechs and Slovaks - Czechoslovakia - was established. Although the existence of this state de facto ended in 1938 by the surrender of the so-called Sudetenland, or by the establishment of the Nazi Protectorate of Bohemia and Moravia and the emergence of the quasi-independent Slovak state in 1939, this year is still perceived by the majority of the Czech population as the foundational moment of modern Czech history and the beginning of Czech political independence.

5 Cf. e.g. Vladimír SRB, Tisíc let obyvatelstva $v$ Českých zemích (on-line), at: http://snem.cirkev.cz/download/Srb.htm, retrieved June $6^{\text {th }} 2015$. Comparing the data from the census of 1910 and that of 1921 shows that in that period the Catholic Church lost more than 1,200,000 members. An important part was played by the massive exit from the Catholic Church after 1918 (almost 1.5 million members) and the founding of the national Czechoslovak Church in 1920, by which most ex-Catholics were absorbed. Cf. David VÁCLAVÍK, Náboženství a moderní česká společnost, pp. 76-92. 
harshest ideological struggle between the communist regime and religious institutions, especially the Catholic Church, was taking place, accompanied by the mass persecution of Catholic priests as well as influential lay persons, but since the 1960s, when the war and post-war generation reached productive age. ${ }^{6}$ An unambiguous decrease was, e.g., recorded in important religious rites (baptisms, weddings etc.). ${ }^{7}$

In the 1970s and 1980s traditional church religiosity further lost its position and ceased to be attractive for a great part of the population. But only a small part of the population supported an ideologically and politically grounded explicit 'atheisation' of the society. According to a survey realized in 1979 by the Institute for Investigating the Public Opinion, "only 15\% of the respondents agreed with the atheisation policy of the state, whereas $67 \%$ held that it is best to ignore religion". ${ }^{8}$

These trends continued until the fall of the communist regime in 1989 and, after a brief religious revival at the beginning of the 1990s, ${ }^{9}$ can still be encountered in contemporary Czech society.

In any case it is necessary to say that despite the evident impact of the communist regime on the Czech population's relationship to religion it is not possible to categorically state that it is the only and main cause of the 'atheisation' of the Czech population. It appears much more adequate to claim that the communist regime only deepened a historically older distrust in religious institutions and reinforced the religious indifferentism of a great part of the population. ${ }^{10}$ This raises the question of whether the contemporary Czech 'atheism', rather than a consequence of politico-ideological agency, is not a product of the progressing modernization of Czech society, in which an important role was played by a paternalistic state with a fairly extensive and relatively functional social system, supplemented by some other factors, among which demographic changes after 1945 resulting in the ethnical and cultural homogenization of Czech society ${ }^{11}$ are prominent. Czech 'atheism' would thus in fact predominantly take the form of apatheism manifesting itself in a high level of disinterest in religious issues, rather than the conscious rejection of religious faith.

\section{Czech society and the Catholic Church in the context of pluralist society}

In the above context the attitude of the majority of the Czech population after 1989 must also be viewed. But at the same time it is necessary to realize that even in the last twenty five years the

6 Cf. e.g. David VÁCLAVÍK, Český ateismus ve dvacátém století. K vývoji a institucionalizaci v letech 1948-1989, Soudobé dějiny 2-3/2007, pp. 471-488.

7 In mid-1970s there were less than $30 \%$ of baptized children and less than $12 \%$ church marriages in most regions of Bohemia. In Moravia the average numbers of the baptized were among 50\% and 60\%. In most Moravian regions church marriages reached the span of 30-50\% and only in very few Moravian regions crossed the 50\% line. Cf. Zdeněk BOHÁČ, Atlas církevních dějin českých zemí 1918-1999, Kostelní Vydří: Karmelitánské nakladatelství, 1999, map no. 4. In the 1980s the decrease continued. There was also a marked drop in church service attendance: in late 1960s 8-10\% inhabitants took part, by late 1980s the number had dropped below $6 \%$. The decrease was more profound in non-Catholic denominations. As in the case of baptisms and church marriages there were great differences among regions in church service attendance - the lowest in the former Sudetenland, the highest in the traditionalist regions of southern and central Moravia.

8 Marie DRAŽILOVÁ et al., Výzkumná zpráva 79-03: Světonázorová orientace občanů ČSSR, Praha, manuscript, 1979, p. 78.

9 Cf. e.g. Lenka VÁCLAVÍKOVÁ HELŠUSOVÁ \& David VÁCLAVÍK, Institucionalizovaná podoba religiozity a její projevy v české republice v letech 1989-2000, Religio: Revue pro religionistiku 2/2006, pp. 45-64.

10 Cf. e.g. David VÁCLAVÍK, Náboženství a moderní česká společnost, pp. 98-111.

11 Before WWII the ethnic composition in the Czech lands was quite diversified. Besides the ca. 7 million Czechs there traditionally lived a strong German community (ca. 3 million), about 150 thousand Jews, not quite 100 thousand Poles and other ethnic minorities. WWII and the subsequent events resulted in an almost complete ethnic homogenization of Czech society, in which almost $97 \%$ inhabitants profess Czech nationality on a long-term basis. 
attitude of the Czech public to the Catholic Church has been quite complex. In the first years after the so-called Velvet Revolution their attitude was rather positive and accommodating. To a certain extent it is possible to say that in that period the Catholic Church was at the height of its popularity (at least in the perspective of the last seventy years) and could get the impression that the atheisation and anti-Catholicism of the Czech nation were matters of the past.

The positive image of churches and religious societies at the beginning of the 1990s is testified to by the fact that at that time credence in churches was at one of the highest levels ever recorded in relevant sociological surveys. In 1990 51\% of citizens trusted the churches, 27\% harboured distrust towards them and $22 \%$ could not tell. But in subsequent years the trust in churches again began to fall; after 1993 distrust of them rose above 50\% and it stayed above this line practically until the end of $1990 \mathrm{~s}$, when Czech society's attitude towards the Catholic Church cooled again markedly in connection with the restitution debates. Since then the trust in churches, which is fundamentally determined by the Czechs' relationship to the largest of them, has been at a very low level, as evinced by the latest available data. According to it (CVVM survey of October 2015) only 23\% of respondents trust or somewhat trust churches, whereas $64 \%$ proclaim distrust of them. ${ }^{12}$

The facts stated above point to one essential feature of the Czech attitude to Catholicism which, in my view, fundamentally limits the possibilities of the active and positively perceived agency of the Catholic Church and some of its representatives on the Czech population. This limitation is an unambiguous "flattening" of Catholicism to its institutionalized expressions in the eyes of the majority of the Czech public, and thereby the marginalization and often outright ignorance of its other aspects and dimensions. To put it briefly: many activities of the Catholic Church in the social sphere, in dialogue with modern society or inter-religious dialogue, including the results of the Second Vatican Council, are invisible to most Czechs, because they are overshadowed in their eyes by their own construct of the Catholic Church as a problematic institution.

However, this 'overshadowing' is definitely not one-dimensional or homogeneous in all strata of the Czech population. As shown above, even in the unsettled times of the second half of the $20^{\text {th }}$ century there were periods in which trust in the Catholic Church grew, even to the extent that it was respected even by the religiously, apatheistic, majority of the population, and even by those who viewed themselves as agnostics or atheists. The last years of the communist regime and the first years after 1989 most certainly belong among these periods.

Two factors played a decisive part in that. First, the fact that the Catholic Church came to be more generally regarded as a certain antipode (especially in respect of worldview and morality) to the corrupt normalization regime. A second important factor was the 'personality strength' of persons associated with Czech Catholicism. They were certainly not only significant figures of the Church, headed by Cardinal Tomášek, but also the then Pope John Paul II. That is witnessed by the evaluation of the visit of Pope John Paul II in 1990, which became the most important intra-political event after the first free election. The absolute majority of inhabitants regarded it as very important, as evinced by the fact that $75 \%$ of the population followed its course.

12 It is basically a confirmation of a long-term trend, observable since the mid-1990s, when trust in churches and religious societies dropped to $30 \%$ for the first time. At that level it remained with minor fluctuations until 2006, when it began to drop further. Credence in churches was lowest in 2012, when trust in them dropped to $20 \%$. The other pole of the scale is occupied by the army, the police and some media. For further data see CVVM AV ČR, Dưvěra některým institucím veřejného života v řijnu 2015. Tisková zpráva (on-line), at: http://cvvm.soc.cas.cz/media/com_form2content/documents/c1/a7447/f3/po151119.pdf, retrieved June $6^{\text {th }} 2015$. 
However, it is necessary to say that the 'positive' image of the personalities of the Catholic Church was constructed not based on some deep or systematic interest in their attitudes, opinions or thoughts, but rather on their 'virtual-media' presentation. ${ }^{13}$ That ultimately explains why at that time Czech society, in many opinions rather liberal and in many respects sceptical and rather materialistically oriented, esteemed so highly a representative of rather conservative thought, whose particular opinions and attitudes were frequently in direct opposition to the attitudes of the majority of the Czech population. ${ }^{14}$

On the other hand it is also necessary to say that the 'disenchantment' that occurred roughly in the mid 1990s was most certainly not the result of the discovery of some idea or value discord, but rather a consequence of the 'fading out' of the revolutionary zeal and gradual integration of the Catholic Church into the official structures of political, cultural and social life, which led to the loss of the 'aureole' of the political and social-cultural alternative Catholicism had had in the preceding years.

The departure of some charismatic personalities (especially Cardinal Tomášek) and the advent of less distinctive personalities who were unable to address broader groups of the population, whether by form or content of their attitudes, and the problematically perceived attitudes of official representatives on issues such as the church restitutions mentioned above only served to emphasize and perhaps accelerate this regress.

Other explanations accenting the inability or unwillingness of a part of the Catholic Church to implement the the reform program of the Second Vatican Council on its dogmatic level are to a certain extent a consequence of a misunderstanding of the complex and intricately structured relationship between religion and modern society. The Catholic Church had (and in a certain respect still has) 'problems' with implementing reforms in the other countries of the former Soviet block as well and it has by far not led to the weakening or point-blank drop in the positions and role of the Church. Rather, some authors, especially ones who try to render the problem from the position of 'initiated and involved' insiders, tend to overestimate the role of dogmas and worldview clashes.

As many surveys and analyses have shown, ${ }^{15}$ these issues have little impact on behaviour and attitudes in the religious sphere, not only for those who are somewhere along the borderlines of the individual religious groups, but even for their very members. Two factors have proved to be more momentous. One is the ability to address by means of intelligible language and issues regarded by contemporary humans as relevant and intelligible. The other is daily practice, the ability to transmit attitudes, values and opinions from generation to generation and the associated ability to retain trustworthiness and legitimacy. With some simplification it is possible to say that often and it holds in this case too - as it is not so important what we say, but how we say it, so it can be much more important how we do things, rather than what we do. Such rather highly pragmatic

13 A good illustration of this 'contradiction', due to which key representatives of the Catholic Church, especially Cardinal Tomášek, were perceived as being close to the anti-Communist dissent, is the fact that, e.g., towards the most important dissident organization, Charta 77, Cardinal Tomášek long maintained quite a distance. One could even say that Cardinal Tomášek, as the most important representative of the Catholic Church, took a very reserved attitude to Charta 77 and justified his stance by the 'political' neutrality of the Church.

14 This fact is evident especially on comparing the attitudes of the majority of the Czech population to issues such as, e.g., divorces, abortions, openness to sexual minorities and generally to the liberal-materialist value orientation with the respective attitudes of the Catholic Church.

15 In the Czech milieu no such explicitly focused study has been published, but with respect to similar trends in all modern societies this fact can be assumed. Of foreign studies on the issue the work Religious Literacy by the American sociologist Stephan Protero is worth mentioning. Cf. Stephan PROTERO, Religious Literacy: What Every American Needs to Know - and Doesn't, New York: Harper One, 2008. 
thought can on the one hand be viewed as the cause of an internal split and a cynical attitude to many problems, but on the other hand it will facilitate a better understanding of the behaviour of many key actors.

In this context it is fairly important that the aspects mentioned above do appear in some Church documents. One of them is the pastoral constitution Gaudium et spes, even though fifty years have elapsed since its publication. Chapter II (The Community of Mankind) or chapter III (Man's Activity Throughout the World) of its first part, as well as chapter III (Economic and Social Life) or chapter IV (The Life of the Political Community) of the second part can be a good starting point for forming a new pastoral strategy.

The application of many principles and observations contained in this document can also facilitate a better and deeper understanding of a number of contemporary problems and issues, or postulate some possible solutions to them. It will apparently be crucial if it is possible to overcome the distrust of a large part of the Czech public, including its cultural, political and economic elites, towards the Catholic Church. That, however, will not be decreased by an official declaration of principles, but by a clear and perceptible change of everyday practice. In the Czech context in particular, by a change as a result of which the Catholic Church will be perceived as a trustworthy alternative to, not as part, however peculiar and in many respects unwanted, of the establishment.

One must realize that one of the most important transformations of modern Western society, at least in relation to religion, is its pluralization and breakdown of vertical structure. All that leads not only to a decline in the monopoly of some religious groups (e.g. the Catholic Church), but also to a situation in which an alternative is no longer just one (marginal) possibility, but becomes one of many possibilities. This fact seems to correspond with one of the most widespread diagnoses or rather paraphrases of the contemporary relationship between religion and modern society, which the American sociologist Clark W. Roof formulated as the situation of a spiritual marketplace. ${ }^{16}$

In this respect it is important not only whether a given religious group is able to react to topical issues often beyond its traditional interest, but also how intelligibly and how fast it is able to react to them. One can say that with respect to documents such as the constitution Gaudium et spes the ability or lack of ability to implement them no longer seems crucial, but primarily the ability or lack of ability to update them, recast them to particular 'everyday activities' and then present them.

In this context it is also possible to understand the 'cautiously positive' image of Pope Francis, ${ }^{17}$ which is due not only to his immediacy and art of communicating in an intelligible way with different, often quite disparate groups of society, but precisely also to his ability to bring many topics and problems up to date and his awareness of the importance of the mundane. Of course, that does not mean that the positively perceived activities of the contemporary Pope are leading to some fundamental change in the perception of the Catholic Church in Czech society. They will probably only lead to 'certain corrections' in the attitudes of some social strata. The crucial part will be played, quite logically, by the ability of the Czech Catholic Church to present itself as a trustworthy alternative in the sense mentioned above, an alternative that will be able to react to

16 Cf. Clark W. ROOF, Spiritual Marketplace, Princeton - Oxford: Princeton University Press, 2001, pp. 3-15.

17 According to a survey published in January 2016 by the agency STEM, 30\% respondents perceive the present Pope Francis very positively and $44 \%$ perceive him rather positively. As a result the Pope appears as the most positively evaluated personality of world politics. The question remains how the Czech public would understand him outside the context of "world politics". 
the ever faster changing problems and requirements of contemporary Czech society in a trustworthy and intelligible manner.

\title{
The Catholic Church through the Eyes of Contemporary Czechs and Contemporary Czechs through the Eyes of the Catholic Church Between Distrust and Expectation
}

\begin{abstract}
Czech society is traditionally viewed as strongly anti-Catholic and at the same time highly secularized or even atheistic. However, the two claims, though they are frequently regarded as almost a priory, conceal a number of questions and misunderstandings and reflect a stereotypical understanding of the relationship between religion and modern Czech society. The paper focuses first on a clarification of the fairly complex and multi-layered relations of Czech society to the Catholic Church, especially in the second half of the $20^{\text {th }}$ century. It points out a fairly fundamental shift occurring in the last twenty years, when a growing number of Czechs and Moravians incline to the opinion that Catholicism (and Christianity as a whole) is rather an expression of cultural identity, not an expression of institutional membership.
\end{abstract}

In the second part the paper focuses on the question what part 'modernization' tendencies associated with Second Vatican Council and the effort of some top representatives of the Catholic Church to 'adapt' the agenda of the Catholic Church to contemporary problems have played in the transformations of the relationship of contemporary Czech society and Catholicism. This part aims to answer the question $\mathrm{s}$ of whether and how dialogue between the contemporary Catholic Church and the majority, religiously highly noncommital Czech society is possible.

Keywords: Catholic Church, Czech society, identity, Second Vatican Council

\section{Contact}

\section{Assoc. Prof. Dr. David Václavík}

Masaryk University Brno

Faculty of Philosophy, Department of Religious Studies

Arna Nováka 1/1, 60200 Brno

vaclav@phil.muni.cz 